\title{
Export performance of Indian Textile Industry in the Post Multi Fibre Agreement Regime
}

Greeshma Manoj*

\section{Abstract}

The Multi Fibre Agreement (MFA) and the quota system which governed the international trade in textiles and clothing came to an end on $1^{\text {st }}$ January, 2005. The quota systems were more restrictive against cotton based fibres, which dominate India's textile exports. Since India has a natural comparative advantage in cotton and cotton based fibres, abolition of MFA was expected to benefit India's cotton industry as well as cotton based textiles and clothing sectors. This paper analyses the export performance of Indian textile industry in the post quota regime in terms of different sub sectors of Indian textiles during the period from 1992 to 2012.The entire period of the study is divided into Pre MFA (1992-2004) and Post MFA (2005-2012). Export performance has been examined in terms of annual growth rate and Compound Annual Growth Rate for the period from 1992-2012. The study finds that the textile exports have registered a strong growth rate in the post quota period (2005-2006), increasing from $2.69 \%$ in $2004-2005$ to $23.14 \%$ in 2005 2006. A comparison of the different sectors of the textile export shows that all the sectors recorded an increase in the export values at different phases of the quota removal. If we compare the pre MFA growth (III Phase) and Post MFA growth (IV Phase), there has been a remarkable

*Assistant Professor, Department of Economics, Christ University, Bangalore, India; greeshma.manoj@christuniversity.in. This paper was presented in the national conference organised by Christ University in collaboration with ICSSR, Bangalore 17-18 March, 2014. 
improvement in the export performance of all the sub sectors. Biggest gainer in the post MFA period is manmade textiles followed by cotton textiles and readymade garments. But India was not able to continue the same momentum in the succeeding years. This clearly indicates that Indian textile industry is facing so many challenges in the post quota regime. Thus, it is imperative to improve the competitiveness of our exports through policy changes, new investment and efficient supply chain management.

Keywords: Textiles and clothing, Quota removal, MFA, Export performance, Trend analysis

The Indian textile and clothing industry is one of the leading segments of the Indian economy and largest in the world with a massive raw material and textiles manufacturing base. It is one of the prominent sectors of Indian economy in terms of its contribution to output, employment and forex earnings. It is the second largest employment provider, after agricultural sector. Currently, it contributes about $14 \%$ to industrial production, $4 \%$ to the GDP, and $17 \%$ to the country's export earnings. It provides direct employment to over 35 million people, which includes a substantial number of SC/ST, and women. (Ministry of Textiles Annual Report 2012-13). Though India maintains a very low share in the global textiles trade (3\%), it is one of the major items in India's export basket. The exports of textiles from India account for about one third of India's total exports.

The Indian textile industry has significant presence in the world textile economy by virtue of its contribution to world textile capacity and production of textile fibres/yarns. This industry contributes about 20 percent to the world spindleage of $166.36 \mathrm{mn}$. spindles and 3 percent to the world rotor age of $7.81 \mathrm{mn}$. and has the second highest spindleage in the world after China. With almost $5.7 \mathrm{mn}$. looms (including handlooms), this industry has also the highest loomage (including handlooms) in the world and contributes about 64 percent to the $8.9 \mathrm{mn}$. world loomage. Even excluding handlooms, this industry contributes 42 percent to the world loomage of $4.38 \mathrm{mn}$. The contribution of this industry to the world production of textile fibres and yarns including jute at about $6.0 \mathrm{mn}$. tons 
is about 12 percent. In the world textile scenario, it is the largest producer of jute, second largest producer of silk, third largest producer of cotton and cellulosic fibre/yarn and fifth largest producer of synthetic fibre/yarn. It is also the third largest producer of cotton yarn.

Despite the textile Industry's strong presence in world textile economy in terms of production of fibre/yarn and fabrics, its share in world trade is a meagre 3.11 percent as against a share of 6.13 percent and 8.3 percent of even small countries like Germany and Italy respectively, which don't even have any worthwhile fibre/yarn production base. China, which has a comparable raw material base enjoys a textile trade share of 13.75 percent. The primary reason for our low share in international trade is the predominance of low value items in our export basket and our insignificant presence in man-made textiles which predominates world textile trade with a 70 percent share. (Textile Committee Report, 2012).

Textile goods including handicrafts, jute and coir account for approximately $20 \%$ of total exports from the country, and are the largest net earner of foreign currency as the import content of textile goods is very little as compared to other major export products. India exports a wide range of textile items, such as cotton yarn and fabrics, man-made fibre yarn and fabrics, wool and silk fabrics, made-ups and apparel. Readymade garments account for about $42 \%$ of total exports of textile goods. Major markets include the EU, US, Canada, Japan, the UAE and Switzerland. Cotton textiles (yarn, fabrics and made-ups) occupy more than two-thirds of exports of all fibres, yarns, fabrics and made-ups.

\section{Trade Agreements in Global Textiles and Clothing Trade}

Global trade in the textile and clothing industry has long been governed by the Multi Fibre Agreement, which set national quotas for exports of textiles. The Multifibre Arrangement grew out of a series of such voluntary export restraints imposed by the United States and Europe on large Asian textile and clothing exporters (Spinanger, 1999). The first of such agreement was in the form of a Short Term Arrangement Regarding International Trade in Cotton Textiles (STA) in 1961 under the General Agreement on Tariffs and Trade (GATT). This short-term international agreement authorized the limitation of cotton textile imports for a 1-year period (1960-1961) if it caused market disruption. The STA was followed by Long Term Agreement Regarding International Trade in Cotton 
Textiles (LTA) in February 1962 which was negotiated among 22 major trading nations to allow importing nations to use quotas to avoid market disruption. It provided for automatic annual increases of 5\% in restraint levels and for bilateral consultations. The LTA was renewed in 1967 and 1970. The multi-fibre arrangement was later negotiated in 1974 to broaden the scope of regulation as well as to provide a framework of rules and procedures under which countries can impose import restrictions.

India had bilateral arrangement under the MFA with developed countries such as US, Canada and countries in the EU. Almost $70 \%$ of total garment exports and $40 \%$ of India's textiles exports have gone to the quota countries mainly USA, EU (15) and Canada. MFA not only restrained international trade but was discriminatory in its application. It was particularly targeted at low cost textile exporting countries to restrict the imports into the developed countries. The system was designed to protect the domestic industries of the United States and the European Union (EU) by limiting imports from highly competitive suppliers such as China (Thoburn, 2009).

The Agreement on Textile and Clothing (ATC) came into force in January 1995 and replaced the Multifibre Agreement. ATC was a transitory regime between the MFA and the integration of trading in textiles and clothing in the multilateral trading system. The ATC envisaged the dismantling of the Multi Fibre Agreement over 10 year period (1995-2004). The ATC provided for (a) progressive elimination of quotas in selected products in four stages during the transitional period ending in 2005 (b) increase in quota growth rates on remaining products at subsequent stages. In addition to gradually removing quotas, the ATC improved developing countries' access to developed-country markets by accelerating quota growth over the four phases of quota removal.

Table 1: Schedule of Quota Integration under ATC

\begin{tabular}{|c|c|c|}
\hline Stage & Date & $\begin{array}{c}\text { Percentage of product to be } \\
\text { brought under removal of quotas }\end{array}$ \\
\hline I & 1 Jan, 1995 & 16 \\
\hline II & 1 Jan, 1998 & 17 \\
\hline III & 1 Jan, 2002 & 18 \\
\hline IV & 1 Jan, 2005 & 49 \\
\hline
\end{tabular}

Source: WTO 
With the termination of the Agreement on Textiles and Clothing (ATC) at the end of December 2004, all textiles and clothing products were fully subject to multilateral disciplines under the rules of the World Trade Organization (WTO). Thus, after three decades, the textile industry was opened to free competition at the international level from Jan 1, 2005 and this has launched a new era in the textiles and apparel trade.

One of the major perceptions about the removal of quotas was that after the removal India would become a major beneficiary because of the advantage of large manufacturing base and a large supply of relatively low cost skilled worker. Apart from this there were so many other factors also which provides competitive edge for India over the competitors like an impressive design expertise and largest producer of yarn and fabrics. The elimination of MFA quotas is expected to create a new environment for world trade in textiles and apparel by vastly increasing the scope for developing countries to expand their exports and thereby creating employment in this sector. It is also claimed that the prospective abolition of these quotas will not necessarily generate automatic benefits to individual countries; the competition will also be fierce. The abolition of the quotas will create opportunities for developing countries, but will also expose them to additional competition from other, formerly restrained, exporters. The outcome for any individual country will depend heavily on its policy response. Countries that take the opportunity to streamline their policies, and improve their competitiveness, are likely to increase their gains from quota abolition.

\section{Review of Literature}

Studies conducted prior to 2005 quota phase-out predicted that once quotas were lifted and all WTO members had unfettered access to developed countries' markets, many of the smaller Asian countries would drastically lose market share. These early studies and simulations also predicted that China would benefit the most from the quota phase-out, as a surge of garment and textile exports was expected to the detriment of the smaller exporting countries (Avisse and Fouquin 2001; Diao and Somwaru 2001; Terra 2001). Several studies have investigated the impact of quota elimination on the global textile and clothing trade using a variety of different methodologies (Aziz et al., 2003; Kathuria, 2001). However, they disagree on the impact of quota elimination on developing 
countries. The majority of the studies reviewed by international organisation such as the WTO, the World Bank, the Asian Development Bank and the United Nations, presumed that there would be enormous gains for both developed and developing countries such as India after the removal of quota restrictions. However, some writers such as Spinanger (1998), and Martin and Winters (1996) hold much more cautious views, particularly with regard to developing countries, on this scenario after 2005. Their assertion is that developing countries would experience negative results after the elimination of textile quota restrictions. They hold that opinion with regard to almost all the developing countries. Ananthakrishnan \& Chandra (2005) analysed the impact of the quota elimination on India using Global Trade Analysis Project 6 in two scenarios. Scenario I assume a full elimination of quotas, while scenario II assumes a partial elimination of quotas for China and a full elimination for other countries. The results of the simulations do not present an optimistic scenario for India in terms of export growth of Textiles and Clothing in quota free world (Scenario I). They also show that Indian exports of textiles and clothing will continue to expand in the presence of the safeguards on China, but will be adversely affected once these are lifted. (Scenario II).

(Chadha et al., 1999)) analysed the potential gains from abolition of MFA for developing countries, particularly India by using a 23 sector multi country Computable General Equilibrium (CGE) NCAER-UM model of World Trade, Production and Employment. Trade liberalisation in textile and apparel sectors, resulting from MFA phase out, will stimulate production of these labour intensive sectors in India, Rest of South Asia (RSA-Bangladesh, Nepal, Pakistan and Srilanka), ASEAN (ASNIndonesia, Malaysia, Philippines and Thailand) and Newly Industrialising Economies (NIE- Hong Kong, South Korea, Singapore and Taiwan). Maximum welfare increase is observed in South Asia other than India. The analysis also showed ASN region as the major gainer, in percentage terms, in the output of textiles (14.5\%) followed by NIE (8.5\%), RSA $(7.5 \%)$ and IND $(5 \%)$. India turns out to be a major proportional gainer in exports of both textiles as well as clothing sectors ( $26 \%$ and $42 \%$ ) followed by ASN (19.5\%), RSA (17\%) and NIE (8\%). 
Chadha, Pratap, Bandyopadhyay, Sachdeva and Kurien (2000) expect India to experience welfare improvements of $\$ 1.9$ billion (in 1995-US\$) from the phase-out of MFA quotas, which corresponds to more than half of the country's total Uruguay Round gain. These gains are likely to have further increased in recent years, as export tax equivalents of Indian MFA quotas for textiles and clothing have risen over time.

Elbehri, Hertel and Martin (2003) analyse the implications of domestic policy reforms in India in the context of trade liberalisation. The study find that if labour productivity in Indian textiles and clothing industries would increase by 67 per cent to reach the level enjoyed by China, the benefits from ATC reform for the country would more than double.

International Labour Organization (2005) opined that the competitiveness of the Indian textile and apparel industry in the world market is dependent on several factors. One of the most important factors is comparative advantage gained from its labour-abundant economy. Labour costs in India are among the lowest in the world. Another important factor is the rich supply of raw materials. India is the third largest cotton producer in the world, with 25 percent of the world's cotton-growing acreage, which is the fourth highest in the world, and accounts for 15 percent of world cotton output following the USA and China. India is also the second largest producer of silk, the largest producer of jute, and one of the largest production bases for cotton/denims and blends of linen.

Juliette Milgram Baleix (2004) studied the impact of the phasing out of the QRs on European clothing imports within the frame work of the phase out MFA by using the gravity equation. The phasing out of QRs would lead to an increase of $20 \%$ in European imports. Certain countries like Vietnam, Korea and China, whose exports are systematically subject to QRs, will have an increase in their exports to the EU of close to a maximum of $37 \%$. Imports of certain categories of products like sportswear, pull overs and sweaters, knitted or crocheted anoraks, TShirts and knitted shirts, trousers and bloused, would increase more significantly than others. The suppression of the quotas will lead to a $20 \%$ increase in EU clothing imports. China, India, Korea, the Czech Republic and Poland would be the main countries of origin of this increase. For those countries which already benefit from free access to the EU, the new trade diversion will cause them to suffer the consequences. 
(Kathuria, Martin and Bharadwaj, 2001) analyse the impact of MFA on export garments and textiles focussing on India. The study showed their discriminatory character of MFA. While exporting countries can gain from quota rents, much of this gain is likely to be offset by losses in exports to unrestricted markets, through wastes resulting from domestic rent seeking behaviour or shared with industrial country importers. While the abolition of quotas on international trade in textiles in 2005 will create opportunities for developing countries, it will also expose them to additional competition from other, formerly restrained exporters. The outcome for any country will depend on its policy response. South Asia as a whole will gain from quota abolition, although different countries may experience different result. Countries that take the opportunity to streamline their policies and improve their competitiveness are likely to gain from quota abolition.

Majmudar (1996) has argued that while most gains are expected to move in favour of China and India due to economies-of-scale, the low labour cost countries such as Pakistan, Bangladesh, Indonesia and Philippines are likely to emerge as gainers. In addition, both the US and the EU may continue to favour certain groups of countries which may retain market shares in individual markets.

Nordas, H. K., (August 2004) analysed the impact of the phasing out of the ATC by using the GTAP model and the study's simulations found that, after full implementation of the Agreement on Textiles and Clothing (ATC), China and India will emerge as the biggest gainers in terms of international market share for clothing: In the United States from 16 percent to 50 percent and from 4 percent to 15 percent respectively; in the European Union market from 18 percent to 29 percent and 6 percent to 9 percent respectively. Nordås (2004) points out that the simulation results are driven by changes in relative prices, while they do not capture the influence of time and distance as trade barriers.

Sasidaran \& Shanmugam (2008) tried to analyse the impact of MFA phase out on the efficiency of firms operating in the Indian textile industry by employing the Stochastic Coefficients Frontier Approach. The study estimated the overall and input specific efficiency values for 215 sample 
firms during 1993-94 to 2005-06. The analysis showed that the average efficiency of textile forms declined over the years, indicating the presence of inefficiency in using inputs. The process of liberalisation through the phasing out of quotas has had a negative impact on the overall efficiency levels of the firms. The falling efficiency levels of the firms during the phasing out period indicate the failure of these firms to match the competitive pressures from countries like China in terms of producing their real potential.

Trela and Whalley (1990) analyse the impact of removal of quotas and tariffs between Canada, the EU, the USA and 34 supplying developing countries using a static CGE model. The analysis was based on the assumptions of perfect competition and constant returns to scale and product homogeneity. The study found welfare gains to the extent of $\$ 23$ billion per year from the elimination of tariffs and quotas. Two third of the welfare gain would be accrued to three developed country importers and one third to developing countries. A number of developing countries are expected to be able to increase their exports by several hundred per cent at the expense of production in developed countries. Nevertheless, a few developing countries are expected to face welfare losses from textiles trade liberalisation, as the improved access to developed countries markets would in their cases not compensate for the loss in quota rents. These losses would be more widespread and pronounced, if the textiles market liberalisation would consist of eliminating quotas, but leaving tariffs unchanged, as assumed by the analysts in a second policy scenario. The removal of trade restrictions under the MFA would enlarge world trade of textiles and apparels and developing countries will further gain market share in world total exports. The quota system generated extensive rent seeking and distortions within exporting countries and between buyers and suppliers at the expense of others. (Trela and Whalley, 1990; Nordstorm, 1994; Diao \& Somwaru, 2001)

Verma (2002) examined India's competitive performance in the US and EU markets for multi-fibre arrangement products categories that are important to Indian export market. The study found that Indian garment export to the EU and US markets are export competitive. The study also emphasised on the importance of government policy intervention. Several 
policy reforms that are needed urgently in order to become more competitive in the world market have also been discussed.

From the above literature it is very clear that there are mixed responses with regard to the removal of quota restrictions on the textile trade. It was expected that with quota removal most of the distortions that existed in the global trade of textiles and apparel would gradually disappear and India would gain much from the quota removal. The scrapping of MFA has raised many discussions about the new international trade climate.

\section{Objective of the study}

To analyse the export performance of the Indian textile industry in the MFA regime.

\section{Data Source and Methodology}

The study is mainly based on secondary data collected from the published reports of WTO, Ministry of Textiles and DGCIS, Kolkata. To study the impact of the removal of MFA on the export performance, 20 years time period is taken into consideration. The time period is divided into two: Pre MFA (1992-2004) and Post MFA (2005-2012). Even though the first phase of quota removal took place in 1995, major percentage $(49 \%)$ of trade integration has happened only in the year 2005.

The entire period of the study is divided into Pre MFA (1992-2004) and Post MFA (2005-2012). In the Pre MFA period there are 3 Phases; I phase (1995-96), II Phase (1998-1999) and III Phase (2002-2003) and IV phase (2005-2012). Export performance has been examined in terms of annual growth rate and Compound Annual Growth Rate for the period from 1992-2012.

\section{Analysis and Interpretation}

MFA phase out has changed the entire scenario of textile trade after 2005. Those who could take advantage of the improved situation gained after 2005 while those who were not able to adjust with the changed situation lost their share to major competitors in the international textile trade after the MFA phase out. Table 2 indicates the change in the percentage shares of top exporters of textiles and clothing from 1990-2010. 
Table 2: Top Global Exporters of Textiles and Clothing

\begin{tabular}{|c|c|c|c|c|c|c|c|c|c|c|}
\hline 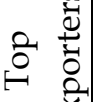 & \multicolumn{2}{|c|}{ ஓু } & \multicolumn{2}{|c|}{$\stackrel{\text { ㅇ }}{\circ}$} & \multicolumn{2}{|c|}{ ஓి } & \multicolumn{2}{|c|}{ 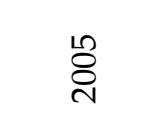 } & \multicolumn{2}{|c|}{$\stackrel{\circ}{\circ}$} \\
\hline & 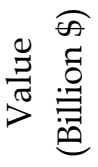 & do & 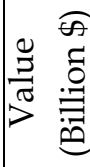 & $\partial^{0}$ & 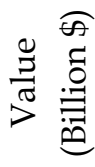 & $\partial^{0}$ & 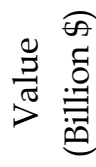 & do & 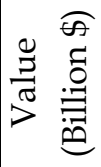 & $\partial^{\circ}$ \\
\hline$\underset{\Xi}{\Xi} \approx$ & $\begin{array}{l}m \\
\stackrel{\infty}{N}\end{array}$ & 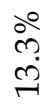 & 尚 & $\begin{array}{l}\stackrel{0}{0} \\
\text { ம) }\end{array}$ & $\stackrel{\infty}{\alpha}$ & $\begin{array}{l}\stackrel{0}{0} \\
\text { ก̇ }\end{array}$ & $\begin{array}{l}\infty \\
\stackrel{\infty}{ } \\
\stackrel{\omega}{\rightleftharpoons}\end{array}$ & $\begin{array}{l}\text { ำ } \\
\text { กิ }\end{array}$ & $\begin{array}{l}0 \\
\vec{n}\end{array}$ & 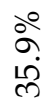 \\
\hline 令 & $\begin{array}{l}0 \\
\text { హ் }\end{array}$ & $\stackrel{\stackrel{\circ}{\dddot{r}}}{\stackrel{+}{+}}$ & 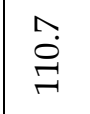 & $\begin{array}{l}\stackrel{\circ}{\Lambda} \\
\stackrel{\circ}{\circ} \\
\stackrel{0}{n}\end{array}$ & $\underset{-}{\circ}$ & $\begin{array}{l}\stackrel{0}{0} \\
\stackrel{0}{0} \\
\stackrel{d}{0}\end{array}$ & 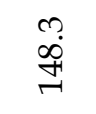 & $\begin{array}{l}\stackrel{\circ}{\hat{N}} \\
\stackrel{0}{0}\end{array}$ & 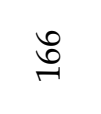 & $\begin{array}{l}\text { ஓ̊̊. } \\
\text { ते }\end{array}$ \\
\hline 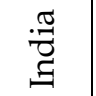 & $\stackrel{\curvearrowright}{\forall}$ & $\stackrel{\circ}{\sim}$ & $\stackrel{0}{\infty}$ & $\stackrel{\circ}{\stackrel{\circ}{N}}$ & 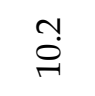 & ๙̊ & $\underset{\sigma}{\sigma}$ & $\begin{array}{l}00 \\
\ddot{n} \\
\ddot{n}\end{array}$ & 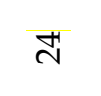 & $\stackrel{\circ}{\circ}$ \\
\hline$\underset{\vec{v}}{\vec{y}}$ & $\stackrel{\infty}{+\infty}$ & $\begin{array}{l}\text { ஷ̊ } \\
\text { in }\end{array}$ & $\overbrace{\infty}^{\infty}$ & $\begin{array}{l}\stackrel{0}{ } \\
\text { io } \\
\text { in }\end{array}$ & 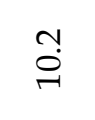 & $\stackrel{\circ}{\circ}$ & $\begin{array}{l}a \\
\infty \\
\sim\end{array}$ & $\begin{array}{l}\text { ळ̊ } \\
\text { ஸे }\end{array}$ & Nี & $\begin{array}{l}\stackrel{\circ}{\Lambda} \\
\text { ले }\end{array}$ \\
\hline 岕 & $\stackrel{0}{\Lambda}$ & $\begin{array}{l}00 \\
\text { ஸे }\end{array}$ & $\underset{ت}{ \pm}$ & $\begin{array}{l}\text { 우 } \\
\text { in }\end{array}$ & $\begin{array}{l}0 \\
\stackrel{0}{\sigma}\end{array}$ & $\begin{array}{l}0^{\circ} \\
10 \\
10\end{array}$ & $\stackrel{t}{\sim}$ & ف0 & $\stackrel{\curvearrowright}{\curvearrowright}$ & $\begin{array}{l}\text { ১0 } \\
\infty \\
\text { i }\end{array}$ \\
\hline$\frac{\infty}{\mathscr{d}}$ & $\stackrel{10}{\wedge}$ & 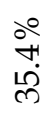 & $\begin{array}{l}a \\
\infty \\
\stackrel{1}{\sigma}\end{array}$ & $\begin{array}{l}\stackrel{0}{0} \\
+ \\
\infty \\
\infty\end{array}$ & $\widehat{\widehat{m}}$ & $\begin{array}{l}0^{\circ} \\
10 \\
\infty \\
\rho^{\circ}\end{array}$ & 官 & 官 & 음 & $\begin{array}{l}\text { 울 } \\
\text { خें }\end{array}$ \\
\hline సేّ & 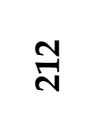 & $\begin{array}{l}\stackrel{0}{0} \\
\text { o̊ }\end{array}$ & 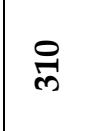 & 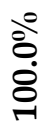 & $\begin{array}{l}10 \\
\text { ñ }\end{array}$ & $\begin{array}{l}\stackrel{0}{0} \\
\text { o̊ } \\
\text { ᄋ̊ }\end{array}$ & $\underset{+}{\infty}$ & $\begin{array}{l}\stackrel{0}{0} \\
\text { o̊ }\end{array}$ & రి & $\begin{array}{l}\stackrel{0}{0} \\
\text { o̊ }\end{array}$ \\
\hline
\end{tabular}

Source: WTO

EU-27, was the largest exporter of textiles and clothing in 1990 with a share of $43.2 \%$ which has decreased to $30.7 \%$ in 2005 , (in the post quota period) and $27.6 \%$ in 2010.China occupied the second position in terms of percentage share of textiles and clothing export with $13.3 \%$ in 1990 which has increased to $27.5 \%$ in 2005 and $35.9 \%$ in 2010. India's share in the textiles and clothing exports was $2.2 \%$ in 1990 which has increased to $3.3 \%$ 
in 2005 and $4 \%$ in 2010. India could marginally improve her performance in the post quota era where as China experienced a huge increase in the share to the extent of $27.5 \%$ in 2005 at the expense of EU-27 and USA. This shows that China was able to diversify its exports in other high value commodities.

Table 3: Share of Indian Textile Exports to Total Exports

\begin{tabular}{|l|c|c|c|}
\hline Year & $\begin{array}{l}\text { Total Textile exports } \\
\text { (Rs. in billion) }\end{array}$ & $\begin{array}{l}\text { Total exports } \\
\text { (Rs. in billion) }\end{array}$ & \% share \\
\hline $1992-93$ & 146.85 & 536.88 & 27.4 \\
\hline $1993-94$ & 188.17 & 697.49 & 27.0 \\
\hline $1994-95$ & 237.01 & 826.73 & 28.7 \\
\hline \multicolumn{4}{|c|}{ I Phase } \\
\hline $1995-96$ & 285.2 & 1063.53 & 26.8 \\
\hline $1996-97$ & 339.2 & 1188.17 & 28.5 \\
\hline $1997-98$ & 344.58 & 1301.01 & 26.5 \\
\hline \multicolumn{4}{|c|}{ II Phase } \\
\hline $1998-99$ & 375.08 & 1397.53 & 26.8 \\
\hline $1999-00$ & 426.39 & 1595.61 & 26.7 \\
\hline $2000-01$ & 517.76 & 2035.71 & 25.4 \\
\hline $2001-02$ & 487.2 & 2090.18 & 23.3 \\
\hline \multicolumn{4}{|c|}{ III Phase } \\
\hline $2002-03$ & 562.71 & 2551.37 & 22.1 \\
\hline $2003-04$ & 597.21 & 2933.67 & 20.4 \\
\hline $2004-05$ & 613.29 & 3753.4 & 16.3 \\
\hline \multicolumn{4}{|c|}{ IV Phase } \\
\hline $2005-06$ & 755.22 & 4564.18 & 16.5 \\
\hline $2006-07$ & 847.21 & 5717.79 & 14.8 \\
\hline $2007-08$ & 870.74 & 6558.64 & 13.3 \\
\hline $2008-09$ & 949.3 & 8407.55 & 11.3 \\
\hline $2009-10$ & 1037.27 & 11429.22 & 10.8 \\
\hline $2010-11$ & 1235.35 & & 12.3 \\
\hline
\end{tabular}

Table 3 shows the share of textile exports to total exports from 1992-93 to 2012-13. The exports of textiles (including handicrafts, jute, and coir) formed $27.4 \%$ of total exports in 1992-93, however, this percentage decreased to $26.8 \%$ in $1995-96$ (I phase of quota removal). Its share remained more or less constant in the II Phase of quota removal (1998-99) to the extent of $26.8 \%$. However this percentage share decreased to $22.1 \%$ 
of total exports in 2002-2003, i.e., in the III phase of quota removal. During 2001-02, a step down in textile exports was seen due to inadequate supply of domestic cotton and high prices of imported cotton. India has faced a major problem caused by unilateral changes introduced by certain trading partners in their rules of origin and these changes have adversely affected textile exports. High price of raw material, high transaction cost and the unfavourable exchange rate were also the reasons which influenced India's textile exports in that year. In the post MFA period (2005-2006), the share of textile exports to total exports decreased to $16.5 \%$. After 2005, India's textile exports share to total exports shows a declining trend. This is partly attributed to the effect of economic turbulence in the major exporting market of EU, US and Canada. Apart from this, in the post MFA period, India is facing stiff competition from Vietnam and Bangladesh in US Market and from Turkey and Bangladesh in the EU market. Bangladesh enjoys duty free access to European markets, while Indian firms have to pay $9.6 \%$ duty on their exports. This has put India in a disadvantageous position in the European market.

Table 4: Growth of Textile Exports (1992-2012)

\begin{tabular}{|c|c|c|}
\hline Year & Total Textile exports (Rs. in Billion) & Growth (in \%) \\
\hline $1992-93$ & 146.85 & 28.14 \\
\hline $1993-94$ & 188.17 & 25.96 \\
\hline $1994-95$ & 237.01 & 20.33 \\
\hline \multicolumn{3}{|c|}{ I Phase } \\
\hline $1995-96$ & 285.2 & 18.93 \\
\hline $1996-97$ & 339.2 & 1.59 \\
\hline $1997-98$ & 344.58 & 8.85 \\
\hline \multicolumn{3}{|c|}{ II Phase } \\
\hline $1998-99$ & 375.08 & 13.68 \\
\hline $1999-00$ & 426.39 & 21.43 \\
\hline $2000-01$ & 517.76 & -5.90 \\
\hline $2001-02$ & 487.2 & 15.50 \\
\hline \multicolumn{2}{|c|}{ III Phase } \\
\hline $2002-03$ & 562.71 & 6.13 \\
\hline $2003-04$ & 597.21 & 2.69 \\
\hline $2004-05$ & 613.29 & \\
\hline
\end{tabular}




\begin{tabular}{|c|c|c|}
\hline Year & Total Textile exports (Rs. in Billion) & Growth (in \%) \\
\hline \multicolumn{3}{|c|}{ IV Phase } \\
\hline 2005-06 & 755.22 & 23.14 \\
\hline $2006-07$ & 847.21 & 12.18 \\
\hline $2007-08$ & 870.74 & 2.78 \\
\hline 2008-09 & 949.3 & 9.02 \\
\hline $2009-10$ & 1037.27 & 9.25 \\
\hline $2010-11$ & 1235.35 & 19.10 \\
\hline $2011-12$ & 1559.36 & 26.23 \\
\hline $2012-13$ & 1685.13 & 8.07 \\
\hline
\end{tabular}

\section{Source: DGCIS, Calcutta}

Table 4 shows the annual growth rate of Indian textile exports from 19922012. Textile exports show a fluctuating trend in the growth rate during the analysis period. The textile exports recorded a growth rate of $20.33 \%$ in 1996-97 (I Phase) as compared to the corresponding period of the previous year. It has decreased to $1.59 \%$ in $1997-98$. This was mainly due to the East Asian Crisis which had a serious impact on India's export. ASEAN countries and Japan were mostly affected by the crisis which led to deterioration in their currency value. When competitor countries in ASEAN devalued their currencies, it had adversely affected India's competitiveness in the international market for textiles. In the II Phase (1998-99), textile exports recorded a growth rate $8.85 \%$ compared to the previous year. In the pre -MFA period textile exports recorded the maximum growth rate in the year 2000-2001(21.13\%), i.e., in the III phase of MFA. In 2001-2002 textile exports recorded a negative growth rate over the previous years. This is attributed to the slowdown in the economies of some of the major importing countries such as US, one of the largest trading partner for Indian textile products and increasing competition from our neighbouring countries like China and Bangladesh. However during 2002-2003, textile exports recorded a positive growth rate of $15.5 \%$ as compared to the corresponding period of previous year.

The textile exports have registered a strong growth rate in the post quota period (2005-2006), increasing from $2.69 \%$ in $2004-2005$ to $23.14 \%$ in $2005-$ 2006. But India was not able to continue the same momentum in the succeeding years. In 2007-08, textiles exports recorded growth of about $2.78 \%$ compared to previous year. This is one of the lowest growth rate recorded during the analysis period. During this time period, textile 
exports suffered badly due to a perceptible slowdown of the US economy and the sharp appreciation of rupee by $15 \%$ against the dollar. Although the rupee has depreciated sharply vis-à-vis the US dollar since April, 2008, the export prospects of the Indian textiles sector continues to be adversely affected. Some of the reasons attributed to this decline are the financial sector melt down and economic slowdown in international markets, liquidity crunch, increased cost of production because of increasing raw material costs, power and other input costs which have affected the profitability of textiles and garments units in India and their exports. USA, the single largest importer of textiles and clothing items, observed a negative growth of $13.22 \%$ and $10.3 \%$ in its imports of T\&C from the world and India, respectively in calendar year 2009. This has adversely affected Indian textile exports in the US market. During 2011-12, textile exports recorded a growth of $26.23 \%$ compared to the previous year mainly because of the weak rupee and revival of demand from major importing countries like US and Euro Zone.

Fig 1: Growth of Textile Exports in the Pre MFA Period (1993-2004) Source: DGCIS, Kolkata

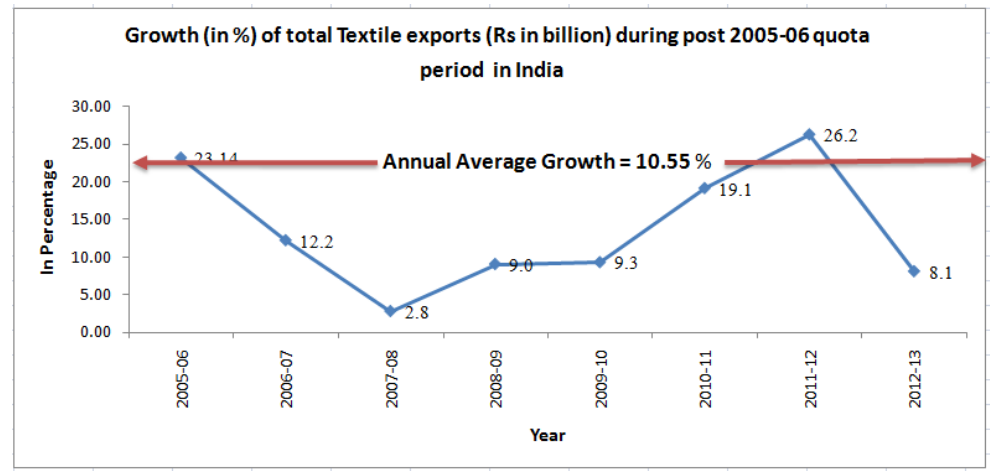

Source: DGCIS, Kolkata

Figure $1 \& 2$ depicts the CAGR for textile exports in the pre and Post MFA period. Annual Growth rate of Pre MFA period (1992-2004) was 11.62\% where as in the post MFA period the CAGR has reduced to $10.55 \%$. This shows that India couldn't take advantage of the removal of quota restrictions because of the intense competition from the competing countries such as China, Bangladesh, Vietnam and Turkey.A levy of 10 
per cent duty on branded and readymade garments and the duty-free access agreement with Bangladesh has added to the woes of the sector. Labour cost in Bangladesh is $25 \%$ cheaper than in India and products made in Bangladesh is 15\% cheaper than Indian products. Earlier, Bangladesh was known for its cheap labor, now it is competing in terms of quality, variety and design.

Table 5: Sector Wise Analysis of Textile Exports

\begin{tabular}{|l|c|c|c|c|c|}
\hline \multicolumn{6}{|c|}{$\begin{array}{c}\text { Total Exports (in Rs.Billion) for various type of textile products across } \\
\text { four stages of liberalization period }\end{array}$} \\
\hline $\begin{array}{l}\text { Type of Textile } \\
\text { Products } \\
\text { Phase }\end{array}$ & $\begin{array}{c}\text { II } \\
\text { Phase }\end{array}$ & $\begin{array}{c}\text { III } \\
\text { Phase }\end{array}$ & $\begin{array}{c}\text { IV } \\
\text { Phase }\end{array}$ & $\begin{array}{c}\text { \% Change } \\
\text { Over III } \\
\text { Phase }\end{array}$ \\
\hline Cotton Textiles & 344.32 & 560.63 & 487.35 & 2764.45 & 467 \\
\hline $\begin{array}{l}\text { Natural Silk Yarn, } \\
\text { Fabrics, Makeups } \\
\text { etc., }\end{array}$ & 15.58 & 46.23 & 50.85 & 121.9 & 139 \\
\hline Manmade Textiles & 82.01 & 169.27 & 244.43 & 1424.47 & 482.6 \\
\hline $\begin{array}{l}\text { Woollen Yarn, } \\
\text { Fabrics, Madeups, } \\
\text { etc. }\end{array}$ & 9.85 & 10.65 & 8.28 & 39.05 & 371.62 \\
\hline $\begin{array}{l}\text { Readymade } \\
\text { Garments }\end{array}$ & 400.25 & 883.32 & 856.52 & 4072.78 & 375.5 \\
\hline $\begin{array}{l}\text { Jute \& Jute } \\
\text { Manufactures }\end{array}$ & 18.67 & 24.3 & 32.63 & 126.43 & 287.47 \\
\hline $\begin{array}{l}\text { Coir \& Coir } \\
\text { Manufactures }\end{array}$ & 6.82 & 10.33 & 11.86 & 61.52 & 418.72 \\
\hline Carpets & 60.1 & 101.72 & 81.29 & 329.7 & 305.58 \\
\hline Mean & 117.2 & 225.8 & 221.7 & 1117.5 & \\
\hline $\begin{array}{l}\text { Standard } \\
\text { Deviation }\end{array}$ & 160.33 & 322.62 & 304.33 & 1531.23 & \\
\hline $\begin{array}{l}\text { C.V (Coefficient of } \\
\text { Variation) }\end{array}$ & 136.80 & 142.88 & 137.30 & 137.02 & \\
\hline & PRE MFA & & $\begin{array}{c}\text { POST } \\
\text { MFA }\end{array}$ & \\
\hline $\begin{array}{l}\text { C.V (Coefficient of } \\
\text { Variation) }\end{array}$ & 138.69 & & 137.02 & \\
\hline
\end{tabular}

Source: Author's Calculation 
A comparison of the different sectors of the textile export shows that all the sectors recorded an increase in the export values at different phases of the quota removal. If we compare the pre MFA growth (III Phase) and Post MFA growth (IV Phase), there has been a remarkable improvement in the export performance of all the sub sectors. Biggest gainer in the post MFA period is manmade textiles which has experienced $482.6 \%$ increase in the export growth compared to the Pre MFA period followed by cotton textiles (467\%), Coir (418.72\%) and readymade garments $(375.5 \%)$.

It is observed from Table 5 that the average export value of textiles were Rs.117.2 crores in the I phase which has increased to Rs.225.80 crores in II Phase. It remained almost same in Phase III with a mean export of Rs. 221.7 crores. In the post MFA period (IV Phase) the average value of textile exports were Rs 1117.50. It is clear from the table that there was a massive increase in the exports during the post MFA period. Interestingly, the Coefficient of Variation (C.V) across each of the phases doesn't show much fluctuation during the post MFA period even though a bigger variation is observed in mean. In totality, the coefficient of variation $(\mathrm{CV})$ between Pre MFA and Post MFA is also negligible with Rs 138.69 and 137.02 crores. This indicates that there is not much variation in the exports of two periods. This result is in consonance with result of the simulation study conducted by AnanthaKrishnan and Chandra (2005) which predicted a very pessimistic future for the Indian textile exports in the post MFA period. This negligible impact of quota removal on Indian textile exports may be due to the intense competition which India faces from competing countries especially China, Vietnam, Bangladesh and Turkey. This result clearly points to the fact that the extent of policy intervention was not adequate during the post MFA period to improve the competitiveness of Indian textile exports. 


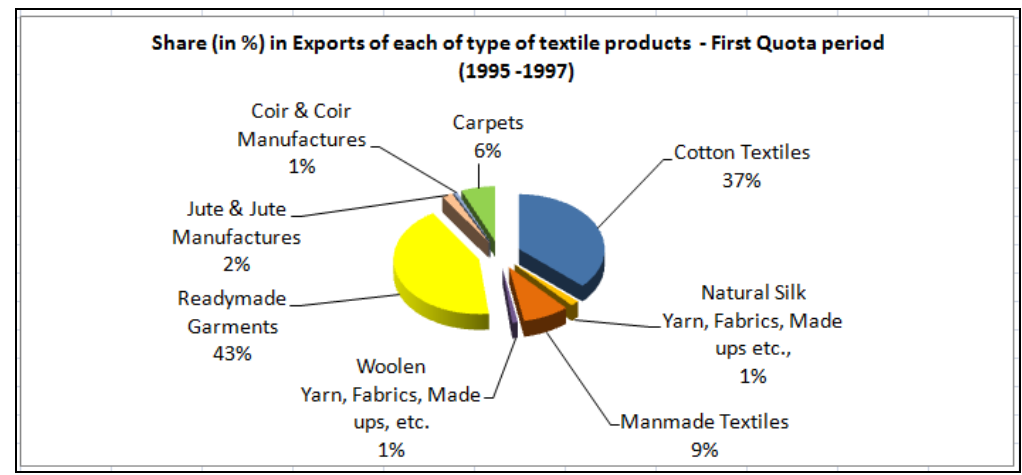

Share (in \%) in Exports of each of type of textile products - Second Quota period (1998 -2001)

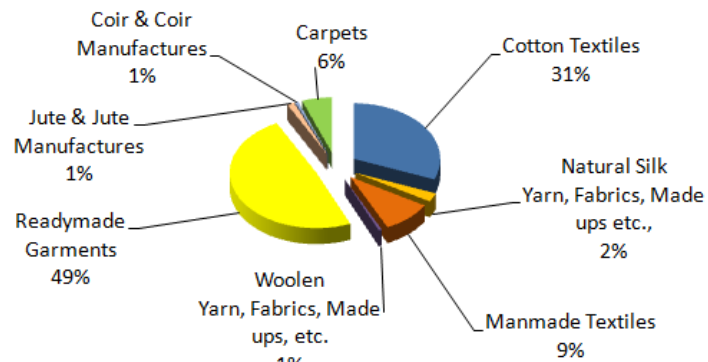

\section{Share (in \%) in Exports of each of type of textile products - Third Quota period} (2002 -2004)

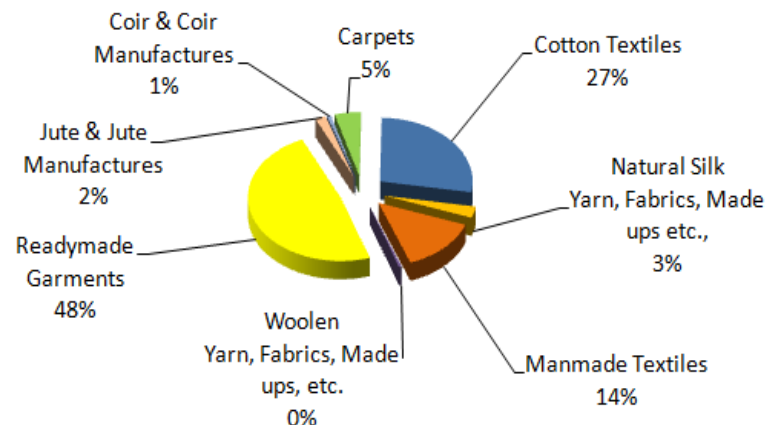




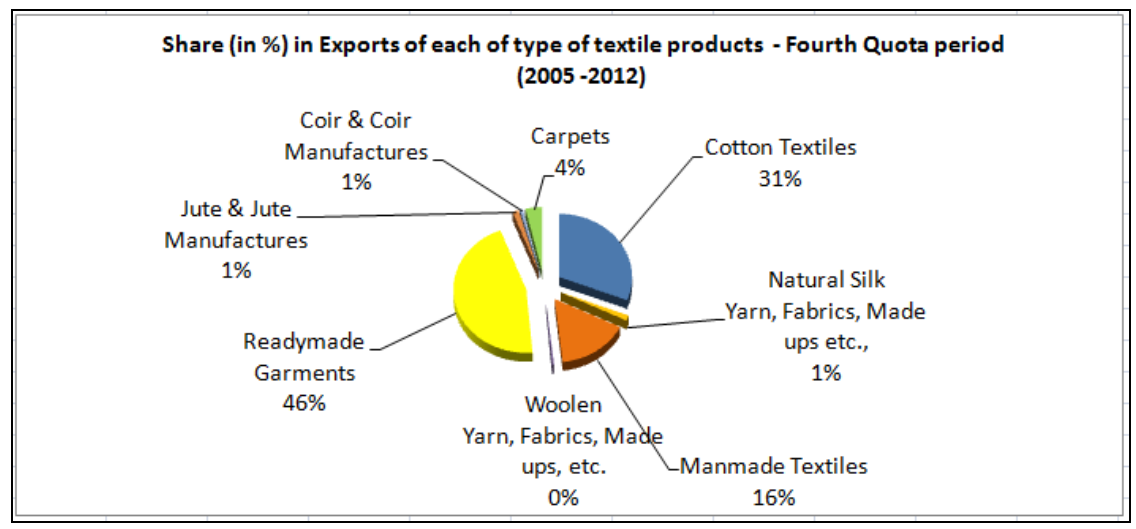

Fig 3: Share of Subsectors to Total Textile Export Source: DGCIS, Calcutta

Figure 3 represents the comparative performance of different sub sectors of Indian textile exports during the four phases of quota removal. Three major contributors to the textile exports are readymade garments, Cotton textiles and manmade textiles. Readymade garments account for about $46 \%$ of total textile exports. Exports of cotton textiles -- which include yarn, fabric and made-ups -- constitute over 2/3rd of total textiles exports (excluding readymade garments). Apparel and cotton textiles products together contribute nearly $72 \%$ of the total textiles exports. In rupee terms, exports of readymade garments witnessed the highest export share $(46 \%)$ followed by Cotton Textiles (31\%), and Man-Made textiles (16\%)in the post MFA period (2005-2012).

The ensuing section throws light on the performance of different subsectors during the policy regime.

\section{Readymade Garment}

Readymade Garment represents value added and less import intensive sub sector, thus deserving a special place. The major importing countries/regions of our readymade garments are the E.U., the USA. Canada, Japan, U.A.E. and Switzerland. Readymade garment share to total exports was $43 \%$ in the I Phase which has increased to $49 \%$ in II Phase. In the III phase RMG share has come down to $48 \%$ and subsequently to $46 \%$ in the post MFA period. 


\section{Cotton Textiles}

Cotton textiles i. e. yarn, fabrics and man-made ups (mill made, power loom, handloom) comprise more than $2 / 3$ of our exports of all fibres/yarns/made-ups. If we compare the performance of cotton textiles over different phases it can be seen that its share has come down to $31 \%$ in II phase and $27 \%$ in III phase compared to $37 \%$ in the I phase. This slowdown in exports of cotton textiles is attributed to fall in cotton yarn exports due to general recession in major markets and the higher price of indigenous cotton. In the post MFA period Cotton textile exports share increased from $27 \%$ to $31 \%$. This increased market share is due to the improved competitiveness of Indian cotton textile sector against six competing countries including China, Bangladesh and Thailand, leading to a higher global market share. The increase in competitiveness has been in areas like technology up-gradation, manufacturing costs and exports.

\section{Manmade Textiles}

Export share of manmade textiles has also shown an improvement in the post MFA period. Its share to total textile exports was $9 \%$ in the I\& II phase which has subsequently increased to $14 \%$ in the III phase and $16 \%$ in the Post MFA period. This increased share may be attributed clear shift in consumer preferences towards man-made fabric and India could take advantage of the new opportunity that has thrown open after the MFA phase out.

\section{Silk Textiles}

This is comparatively a small segment with exports. Share of silk exports was $1 \%$ in the I phase of MFA regime. Its share has increased to $2 \%$ and $3 \%$ in II and III phase respectively. Post MFA phase shows a declining trend in the export share of silk textiles.

\section{Woollen Textiles}

Exports of woollen textile has been showing a declining trend in the III and final phase of MFA. This has been attributed to sluggish market conditions and overstocking in major markets which have reduced the demand for woollen textiles from India. The global financial crisis has resulted in sharp decline in the demand for woollen products during 2008. This would have reduced the exports of woollen textiles during the post 
MFA period. Wool yield in India is low Avg. $0.9 \mathrm{~kg}$ per sheep/ year, against a world avg. of $2.4 \mathrm{~kg}$ per sheep/ year (Australia: $4.5 \mathrm{~kg}$ ). Another area of concern is in terms of the availability of good quality wool. While domestic availability of wool remains a matter of concern, the quality of wool is also not up to the requirements of the Indian wool and woollen products industry, particularly for export purpose. Domestically produced wool is coarse and brittle in nature. The processing and finishing of wool products is a weak link which requires huge capital investment, particularly in the organised sector.

\section{Jute textiles}

Share of jute textiles to total export has fluctuated around 1 to $2 \%$ in all the three phases of MFA. In the post MFA period the share of jute textiles shows a decreasing trend in the analysis period. This declining trend in the exports was caused mainly by decline in exports of Hessian, Sacking and Jute Diversified Products. Jute industry is confronting so many problems in the domestic front because of which this industry is struggling hard for survival. The problems were high labour cost, instability in the production of raw jute, demand erosion, obsolescence of machinery, uneconomic working and competition from synthetic sector (Ministry of Textiles, 2011)

Other subsectors of the textile industry, viz, coir industry, and carpet industry shows more or less same share throughout the study period.

\section{Conclusion}

The above analysis indicates that India was not able to gain much from the removal of quota restrictions. Performance of the industry is not in accordance with the possible predictions of the previous research studies. When we compare the performance of Indian textiles with China it is very clear that India could not gain much compared to China. While China could increase its export share in world textile trade to $35.9 \%$ in 2010 , India accounts for only $4 \%$ of world textile trade.

Indian textile industry is beset with so many problems which will act as an obstacle in the growth prospects of the sector. Main factor that hinder the performance of Indian textile sector is the structure of the industry itself. Indian textile sector has one of the longest and complex supply chains in the world as many as 15 intermediaries between the farmer and 
the final consumer (Varma). This complex supply chain will not only lead to lengthening of lead times, but also adding to cost. The cost of logistics in the Indian textile industry is very high and inflexibility of labour laws has discouraged the expansion plans of the major manufacturers. Many Indian textile manufacturers have shifted or opened new units in neighbouring Bangladesh to take advantage of low labour cost and duty concessions on exports to US and European markets. Apart from this, high cotton cost and low demand on the domestic front have also adversely affected the industry.

There are so many other developments in the international scenario which will act as a hindrance to the growth of Indian textile industry. One of the important developments is the proposed US-led Trans-Pacific Trade Pact (TPP) with Pacific nations. Since India is not a party to TPP, it has got serious implications on Indian textile and clothing industry. After the implementation of TPP, TPP countries can source inputs from TPP countries at the cost of non TPP countries, even if non-TPP countries are not the least cost. This will lead to a situation of trade diversion -moving trade away from more efficient producers to less efficient producers. Though this rule is 'primarily' aimed at restricting the benefits accruing to Chinese manufacturers of yarn and fabrics from further opening of the lucrative US markets for clothing, it will create a comparative disadvantage for all non-TPP member countries, including India.

Another area of concern for India is the export incentives in textiles and clothing. India will have to phase out its export incentives in textiles and clothing to comply with the WTO commitments. Export incentives are given in order to improve the export competitiveness of the exporting country. Export competitiveness is deemed to be achieved if a country's global export share of a specific product group (defined as a section heading of the ITC-HS) is 3.25 per cent or more in two (consecutive calendar) years. India's share in world export of textile and clothing (falling under section heading XI of the HS) already crossed this limit in 2007. As a result, India will have to phase out its export sops for the sector by 2015 (Business Line, 2013)

In addition to international challenges, India's textile industry has also been affected by government decisions such as reduction of drawback rates, withdrawal of interest subvention on export credit, inordinate delay in disbursement of TUFS (technology up gradation fund) claims and 
totally unreasonable increase in minimum support prices for cotton. Apart from this, our textile exports are also affected in terms of cost efficiency. In spite of being fully integrated and credited with a rich and diversified raw material base (from cotton to viscose, silk to woollen and polyester to acrylic), the cost-efficiency of the Indian textile industry is significantly lower than that of China, Bangladesh and Vietnam.

In spite of the above factors there is some ray of hope for India. Factors such as export market price being a little more than the domestic price and the dependence of global clothing companies on Asian countries like China, India, and Bangladesh has enhanced the hopes of the Indian textile industry. India can also take advantage of the various problems associated with Chinese textile industry. China's ability to increase its share in the world trade is affected by factors such as rising domestic demand, scarcity of raw material and other key resources like power and increasing cost of labour. Apart from this Indian textile industries inherent strength such as availability of raw materials, especially cotton, integrated operations and design skills would favour the shift of world export of textile industry to India. Both domestic consumption and increased share of exports will be driving force for the future growth of this sector

\section{References}

A preferential trade pact in textiles between US and Pacific nations will hurt China and India. Business Line, 2013, May 29

Chadha, R., Pratap D., Bandyopadhyay, S., Sachdeva, P. \& Kurien, B. (2000). The Impact of Changing Global Trade Policies on India. SANEI Project Report. New Delhi: National Council of Applied Economic Research.

Chadha, R., Pohit, S., Stern, R.M., \& Deardorff, A. V. (1999). Phasing out the Multi-fibre Arrangement: Implications for India. Paper presented at the Second Annual Conference on Global Economic Analysis, Copenhagen.

Diao, X., \& Somwaru, A. (2001). Impact of MFA Phase-Out on the World Economy: An Intertemporal, Global General Equilibrium Analysis. TMD Discussion Paper No. 79. Washington, D. C.: International Food Policy Research Institute.

Elbehri, A., Hertel, T. \& Martin, W. (2003). Estimating the Impact of WTO and Domestic Reforms on the Indian Cotton and Textile Sectors: A General Equilibrium Approach. Review of Development Economics 7(3), 343-359. 
Francois, J. F., Glismann, H. H. \& Spinanger, D. (2000). The Cost of EU Trade Protection in Textiles and Clothing. Working Paper No. 997. Kiel: Kiel Institute of World Economics.

Francois, J. F., McDonald, B. \& Nordström, H. (1994). The Uruguay Round: A Global GeneraEquilibrium Assessment. Discussion Paper No. 1067. London: Centre for Economic Policy Research.

Hamilton, C. B. (Ed.), (1990). Textiles and Trade and the Developing Countries: Eliminating the Multi-Fibre Arrangement in the 1990s. Washington, D. C.: The World Bank.

Ernst, C., Ferrer, A. H. \& Zult, D. (October 2005). The end of the Multi-Fibre Agreement and its implications for trade and employment, ILO: Employment Strategy Paper 2005/16

Kathuria, S., \&Bhardwaj, A. (1998). Export Quotas and Policy Constraints in the Indian Textile and Garment Industries. Policy Research Working Paper No. 2012. Washington, D.C.: The World Bank.

Kathuria, S., Martin, W. \& Bhardwaj, A. (2001). Implications for South Asian Countries of Abolishing the Multifibre Arrangement. Policy Research Working Paper No. 2721. Washington, D.C.: The World Bank.

Majmudar, M. (1996), Trade Liberalisation in Clothing: the MFA PhaseOut and the Developing Countries, Development Policy Review, 14(1), 536.

Ministry of Textiles (2001), Annual Report 2009-10, Retrieved from http:/ / texmin.nic.in/annualrep/ar_09_10_english.pdf

Ministry of Textiles, India (2012), Compendium of Textile Statistics.

Sasidaran G. \& Shanmugam K. R. (2008). Impact of Trade Liberalisation on the Efficiency of Textile Firms in India. ISAS Working Paper

Spinanger, D. (1991). Experiences with Liberalization Policies: The Case of Textiles. European Economic Review 35: 543-551.

Spinanger, D. (1999a). Textiles beyond the MFA Phase-Out. World Economy 22(4): 455-476.

Trela, I. \&Whalley, J. (1988). Do Developing Countries Lose from the MFA? Working Paper No. 2618. Cambridge/Massachusetts: National Bureau of Economic Research.

Trela, I. \& Whalley, J. (1990). Global Effects of Developed Country Trade Restrictions on Textiles and Apparel. Economic Journal 100(403): 11901205.

Verma, S. (2002). Export Competitiveness of Indian Textile and Garment Industry. ICRIER Working Paper no. 94.

Yang, Y., Martin, W. \& Yanagishima, K. (1997). Evaluating the Benefits of Abolishing the MFA in the Uruguay Round Package, in Hertel, T. (Ed.) Global Trade Analysis: Modelling and Applications. Cambridge, New York and Melbourne: Cambridge University Press. 